\title{
A Study on Techno - Economic Feasibility for Production of Iron Enriched Extruded Snacks
}

\author{
Shraddha Bhople* and Mohan Singh \\ Department of Post Harvest Process and Food Engineering, College of Agricultural \\ Engineering, JNKVV, Jabalpur - 482004, Madhya Pradesh, India \\ *Corresponding author
}

\section{A B S T R A C T}

Keywords

Break even

Analysis, Extrusion,

Brown rice

Article Info

Accepted:

16 December 2017

Available Online:

10 January 2018
The main objective of this analysis was to study on Techno-Economic Feasibility for Production of Extruded Snacks prepared by rice, ashwagandha and spinach powder. In order to determine the techno-economic feasibility three economic parameters i.e. break even quantity, break even sales and break even period were analysed. In break even analysis it was found that in order to produced 15,00,000 units of $20 \mathrm{~g}$ packets of ready to eat extruded snacks of blended flour consisting of blend of Rice: Ashwagandha: Spinach in the blend ratio of 80:6:14 with identified infrastructure the break even quantity is 2327742 units, the break even sales is Rs.1,39,66,452/- and Break even period comes out 380 days. This analysis helps in commercial production of extruded snacks.

\section{Introduction}

In modern food industry today extrusion processing becomes very important procedure. Extrusion technology has become famous technique for preparing ready to eat extruded snacks due to its low cost, versatility and no process effluents (Ficarella et al., 2006; White, 1994). There are number of extruded snacks are available in market. The material/ energy and money required for production considerably bags a high cost, so it is necessary to optimize the technical and economic feasibility of extrusion cooking (Eresh Kumar Kuruba et al., 2017). The aim of this research paper is to analyze the economic feasibility of the extrusion cooking technology. Extruded snacks were prepared by blending of rice flour, ashwagandha powder and spinach powder. The main purpose of break-even analysis is to determine the minimum output that must be exceeded for a business to profit. It also is a rough indicator of the earnings impact of a marketing activity. A firm can analyze ideal output levels to be knowledgeable on the amount of sales and revenue that would meet and surpass the breakeven point. If a business doesn't meet this level, it often becomes difficult to continue operation. The break-even point is 
one of the simplest, yet least-used analytical tools. Identifying a break-even point helps provide a dynamic view of the relationships between sales, costs, and profits. This is very important for financial analysis. Any sales made past the breakeven point can be considered profit (after all initial costs have been paid). Break-even analysis can also provide data that can be useful to the marketing department of a business as well, as it provides financial goals that the business can pass on to marketers so they can try to increase sales. Break-even analysis can also help businesses see where they could restructure or cut costs for optimum results. This may help the business become more effective and achieve higher returns. In many cases, if an entrepreneurial venture is seeking to get off of the ground and enter into a market it is advised that they formulate a break-even analysis to suggest to potential financial backers that the business has the potential to be viable and at what points. Thus the aim of this analysis was to assess the break-even point for commercial production of extrudates.

\section{Materials and Methods}

The raw material used for production of extruded snacks was rice, ashwagandha and spinach powder in blend ratio of 80: 6: 14 . Various unit operations were performed during preparation of extrudates i.e. grinding, drying, conditioning, extrusion-cooking, spicing and packaging etc.

In order to determine the techno-economic feasibility of production of extruded product of rice, ashwagandha and spinach powder three economic parameters i.e. break even quantity, break even sales, break even period were calculated as follows:

Break $\begin{gathered}\text { even } \\ \text { Total fixed cost }\end{gathered}$ quantity =

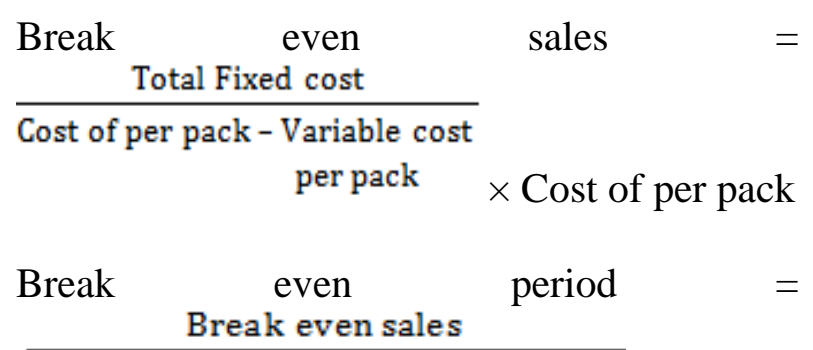

Total number of units produced p.m

\section{Breakeven analysis}

Cost analysis for preparation of ready to eat extruded snacks from the identified best blended rice flour, ashwagandha powder and Spinach powder. In calculating the breakeven point certain assumptions were which are listed below. The selling cost of one unit of 20 gram was fixed as Rs. 6/- because at present the similar products are available at retail price of Rs. 10/- and their selling price at factory retail outlet is Rs. 6/-.

\section{Fixed cost}

Total fixed cost $=60,16,000 /-+12,00,000 /-$

Fixed cost per month $=72,16,000 /-$

\section{Assumptions}

Useful life of machines $=10$ years.

Useful life of building $=20$ years.

Salvage value $=10 \%$ of initial cost.

Rate of interest $=12 \%$ p.a.

Depreciation of machines per year = Fixed cost of machine (C) -Salvage Value(S) Useful life of machine ( $L$ )

$$
\begin{aligned}
& \frac{60,16,000-601600}{10} \\
= & 541440.00 /-
\end{aligned}
$$

Cost of Land and Building per year = $12,00,000$

$$
20=60,000 /-
$$




\section{Cost of machines and equipments}

\begin{tabular}{|l|l|l|}
\hline S. No & Machine/Equipment & Cost in Rupees \\
\hline 1. & Food extruder with accessories & $21,00,000 /-$ \\
\hline 2. & Hammer Mill & $25,000 /-$ \\
\hline 3 & Burr Grinder & $42,000 /-$ \\
\hline 4. & Spice Flavor coating drum & $90,000 /-$ \\
\hline 5. & $\begin{array}{l}\text { Automatic Pouch Packaging Machine (total quantity 3, @ Rs. } \\
\text { 12,00,000 each) Cost inclusive of freight, Installation \& }\end{array}$ & $36,00,000 /-$ \\
\hline Commissioning, taxes, duty and insurance charges. & \\
\hline 7. & Weighing Balance & $26,000 /-$ \\
\hline 8. & Moisture Tester & $50,000 /-$ \\
\hline 10. & Containers for raw materials and finished product. & $28,000 /-$ \\
\hline & Crates & $35,000 /-$ \\
\hline
\end{tabular}

\section{Cost of land and buildings}

\begin{tabular}{|l|l|l|}
\hline S. No & Item & Cost in Rupees \\
\hline 1. & Land area 600 sq. ft. @ Rs. 500 per sq. ft. & $3,00,000 /-$ \\
\hline 2. & Construction cost @ Rs. 1500 per sq. ft. & $9,00,000 /-$ \\
\hline & Total & $12,00,000 /-$ \\
\hline
\end{tabular}

\section{Variable cost}

\begin{tabular}{|c|c|c|}
\hline S. No & Items & Cost in Rupees \\
\hline \multirow[t]{6}{*}{1.} & \multicolumn{2}{|l|}{ Labour Charges } \\
\hline & (a.) One Manager/Supervisor & 25,000/- p.m. \\
\hline & (b.) One operator & 12,000/- p.m. \\
\hline & (c.) One helper & 8,000/- p.m. \\
\hline & (d.) One watchman & 5,000/- p.m. \\
\hline & Total & 50,000 /- p.m. \\
\hline 2. & Electricity charges for $500 \mathrm{~kW}$ in a month @ 7/- per Kw & 35,000/- p.m. \\
\hline \multirow[t]{5}{*}{3.} & \multicolumn{2}{|l|}{ Raw materials required per month } \\
\hline & (a)Rice $(30,000 \mathrm{~kg} \times 0.80$ part $\times @$ Rs 40 per kg.) & $960000 /-$ \\
\hline & (b)Ashwagandha $(30,000 \mathrm{~kg} \times 0.06$ part $\times @$ Rs 400 per kg.) & 720000/- \\
\hline & (c)Spinach $(30,000$ kg 0.14 part $\times @$ Rs 30 per kg.)) & $126000 /-$ \\
\hline & Total & $1891000 /-$ \\
\hline 4. & Spices@2\%@Rs.400 per kg & $2,40,000 /-$ \\
\hline 5. & Packaging material @ 0.25 per packets $(15,00,000 \times 0.25)$ & $3,75,000 /-$ \\
\hline 6. & Repair and maintenance @ 10\% of machine cost. & $601600 /-$ \\
\hline 7. & Insurance charges@10\% of TFC & 67361.28/- \\
\hline & Total & $3259961.28 /$ \\
\hline
\end{tabular}


The result of cost analysis tabulated as follows

\section{S. No. Item}

1. Fixed Cost

2. Variable Cost

3. Variable Cost per pack of $20 \mathrm{~g}$

4. Break even quantity

5. Break even sales p.m.

6. Break even period

Fixed Cost per year $=60,000+541440$

$=601440 /-$

Interest @ $12 \%$ per year $=(601440 \times 12) / 100$

$=72172.80 /-$

Total Fixed Cost $=601440+72172.80$ $=673612.80 /-$

The cost of production, breakeven volume, breakeven sales and breakeven period

\section{Assumptions}

Capacity $=10 \mathrm{~kg}$ raw materials per hr.

Operating time $=10 \mathrm{hr} / \mathrm{day}$

Working days $=26$ day

Total installed capacity of unit in terms of kg. of materials $=30,000 \mathrm{~kg}$

Size of one unit $=20$ grams.

$=15,00,000$

\section{Values Rupees}

Rs. $72,16,000 /-$

Rs. 3259961.28/-

Rs. 2.9/-

2327742 units of $20 \mathrm{~g}$ each

Rs. $1,39,66,452 /-$

380 days. (1 year 15 days)

Assuming the unit to operate at $75 \%$ of installed capacity.

Therefore, total number of units produced per month is $=11,25,000$

Cost of one unit $=$ Rs. $6 /$ - per unit

Variable per unit $=\frac{\text { Total variable cost }}{\text { Units produced per month }}$

$$
=\frac{3259961.28}{11,25,000}
$$

$=2.8977$

$=2.9$ (approximately)

Break even quantity = Total fixed cost

Cost per pack-Variable cost per pack

$$
\begin{aligned}
& \frac{72,16,000}{6-2.9} \\
= & 2327742 \text { units of } 20 \mathrm{~g} \text { each }
\end{aligned}
$$




$$
\begin{aligned}
& \frac{\text { Break } \begin{array}{c}
\text { even sales p.m. } \\
\text { Total Fixed cost }
\end{array}}{\text { Cost of per pack - Variable cost }} \text { per pack } \times \text { Cost of per pack } \\
& =\frac{7216000}{6-2.9} \times 6=1,39,66,452
\end{aligned}
$$

Therefore, from the break even analysis it was found that in order to produced 15,00,000 units of $20 \mathrm{~g}$ packets of ready to eat extruded snacks of blended flour consisting of blend of Rice: Ashwagandha: Spinach in the blend ratio of 80:6:14 with identified infrastructure the break even quantity is 2327742 units, the break even sales is Rs.1,39,66,452/- and Break even period comes out 380 days.
Eresh Kumar Kuruba, Mohan Singh, and Wasiya Farzana. Techno-Economic Feasibility Analysis of Tomato Processing Pilot Plant. Bull. Env. Pharmacol. Life Sci., Special issue 2017; 6(3):51-55.

Ficarella, A., Milanese M, and Laforgia D. Numerical study of the extrusion process in cereals production. Journal of Food Engg. 2006; 73: 103-111.

Houston, D.F., and Kohler, G.O. Nutritional properties of rice. Nutrition Edu. 1970; 1(4): 27-29.

Seth, N.K., and Madhyan, M.L. 2008. Studies on preparation of ready - to - eat snacks from rice - defatted soy flour and winter cherry powder blend by using extrusion cooking technology. Unpublished Ph.D Thesis, Submitted to JNKVV Jabalpur, India.

White, G. Defining the true meaning of snacks. Food Technology International Europe. 1994; 2: 115-117.

\section{How to cite this article:}

Shraddha Bhople and Mohan Singh. 2018. A Study on Techno - Economic Feasibility for Production of Iron Enriched Extruded Snacks. Int.J.Curr.Microbiol.App.Sci. 7(01): 2253-2257. doi: https://doi.org/10.20546/ijcmas.2018.701.272 